УДК 582.284(470)

\title{
The Meruliaceae of Russia. II. Panus
}

\author{
I. V. Zmitrovich ${ }^{1}$, M. A. Bondartseva ${ }^{1}$, L. G. Perevedentseva², A. G. Myasnikov³ , A. E. Kovalenko ${ }^{1}$ \\ ${ }^{1}$ Komarov Botanical Institute, BIN RAS, Prof. Popov str., 2, St. Petersburg, 197376, Russia. E-mail: IZmitrovich@binran.ru \\ ${ }^{2}$ Perm State National Research University, PGNIU, Bukireva str., 15, Perm, 614990, Russia \\ ${ }^{3}$ Moscow State University of Civil Engineering, MSSU, Yaroslavskoe shosse, 26, Moscow, 129337, Russia
}

Keywords: basidiomycetes, broadleaf wood-associated fungi, merulioid fungi, modifications variability, Russia.

Summary. The history of taxonomical study of the genus Panus Fr. (Meruliaceae, Polyporales, Basidiomycota) is considered. A current revision of the genus in Russia was carried out. Two species of the genus Panus were recorded in various regions of Russia, Panus conchatus (Bull.) Fr. and P. lecomtei (Fr.) Corner. For P. conchatus, the lateral ecotype with conchiform pileus and rather dark wine-red to lilac-brown surface is more characteristic. Two main deviations from such a neutral type were described: 1) the chromatic one, characterized by light-colored (red or clay-yellow), usually conchiform pilei [P. conchatus var. inconstans (Pers.) Zmitr., Bondartseva, Perevedentseva, Myasnikov et Kovalenko] and 2) the growth one, characterized by a central (often bulbous) stipe, funnel-shaped cap and strongly inrolled margin $[P$. conchatus var. torulosus (Pers.) Zmitr., Bondartseva, Perevedentseva, Myasnikov et Kovalenko]. For $P$. lecomtei, the ecotype having small eccentric to lateral elegant stipe is considered. However, the stipe shape and size are variable. The stipe can be either central - rather small, with a bulbous base [P. lecomtei var. semirudis (Singer) Zmitr., Bondartseva, Perevedentseva, Myasnikov et Kovalenko], or strongly elongated [P. lecomtei var. stipitata (Malk.) Zmitr., Bondartseva, Perevedentseva, Myasnikov et Kovalenko]. Four new combinations, $P$. conchatus var. inconstans, P. conchatus var. torulosus, P. lecomtei var. semirudis, and P. lecomtei var. stipitata were suggested. It was concluded that Panus represents rather well-delimited genus belonging to merulioid phylogenetic radiation, whose morphotype on essential features of its organization is trametoid, but superficial habitual features make it closer to the lentinoid one. Its essential features are the abundance of fibrohyphae which form textura intricata, slowly growing basidiocarps and strictly lamellate hymenophore. Apparently, such an adaptive structure was generated at arid and warm climatic zones, and only 2 species, $P$. conchatus, and P. lecomtei, have been irradiated into temperate latitudes. The substrate spectrum of these fungi is determined by their insensitivity to substrate moistening and best ability to colonize hardwood, so the greatest number of their finds can be made on stumps and large remnants of stand-formers of corresponding forest areas. In Russia, a reliable association of Panus species to Betula spp. and Populus spp. was revealed. An ecotypic differentiation of the genus Panus is related to the quality of substrate colonized. The basidiocarps, growing over top cuts of the stumps, are characterized by strong central stipe ( $P$. conchatus var. torulosus, P. lecomtei var. semirudis), whereas basidiocarps with sublateral attachment are common on fallen logs. Certain chromatic adaptations ( $P$. conchatus var. inconstans) are associated with an insolation regime of the habitat. During last years, the Panus representatives have attracted an interest in biomedical research development. Their resource potential estimation should proceed from the fact that within Russian territory, such areas as Middle Belt of European Russia, North Caucasus, Altai and other regions of Southern Siberia are promising for replenishing the strains of $P$. conchatus and P. lecomtei.

\section{Мерулиевые грибы России. II. Род Рanus}

\author{
И. В. Змитрович ${ }^{1}$, М. А. Бондарцева ${ }^{1}$, Л. Г. Переведенцева ${ }^{2}$, А. Г. Мясников ${ }^{3}$, А. Е. Коваленко ${ }^{1}$ \\ ${ }^{1}$ Ботанический институт им. В. Л. Комарова, БИН РАН, ул. Проф. Попова, 2, г. Санкт-Петербург, 197376, Россия \\ ${ }^{2}$ Пермский государственный начиональный исследовательский университет, ПГНИУ, \\ ул. Букирева, 15, г. Пермь, 614990, Россия
}

${ }^{3}$ Московский государственный строительный университет, МГСУ, Ярославское шоссе, д. 26, г. Москва, 129337, Россия 
Ключевые слова: базидиомицеты, лентиноидные грибы, мерулиевые грибы, модификационная изменчивость, Россия.

Аннотация. Рассмотрены этапы таксономического изучения рода Panus Fr. (Meruliaceae, Polyporales, Basidiomycota). Проведена ревизия видов, известных для России. Изучены материалы Гербариев Ботанического института им. В. Л. Комарова (LE) и Пермского государственного национального исследовательского университета (PERM). Впервые обощены литературные и гербарные данные о внутривидовом полиморфизме бореальных таксонов рода. Согласно имеющимся гербарным и литературным данным, на территории России зафиксировано 2 вида рода Panus - Panus conchatus (Bull.) Fr. и P. lecomtei (Fr.) Corner. Для P. conchatus наиболее характерен латеральный экотип с раковинообразной шляпкой и довольно темной лилово-коричневой поверхностью. Были описаны два основных отклонения от такого модального типа: 1) хроматическое, характеризующееся светло-красными (красными или глиняно-желтыми) шляпками [P. conchatus var. inconstans (Pers.) Zmitr., Bondartseva, Perevedentseva, Myasnikov et Kovalenko] и 2) ростовое, характеризующееся центральной (часто бульбовидно вздутой) ножкой, воронковидной шляпкой и сильно подогнутым краем [P. conchatus var. torulosus (Pers.) Zmitr., Bondartseva, Perevedentseva, Myasnikov et Kovalenko]. Для P. lесотtei наиболее характерным экотипом является латеральный, с небольшой ножкой. Встречаются экотипы со вздутой центральной [P. lecomtei var. semirudis (Singer) Zmitr., Bondartseva, Perevedentseva, Myasnikov et Kovalenko], либо сильно удлиненной латеральной ножкой (P. lecomtei var. stipitata). Для перечисленных разновидностей было предложено 4 новые комбинации [P. conchatus var. inconstans, P. conchatus var. torulosus, P. lecomtei var. semirudis, P. lecomtei var. stipitata Malk.) Zmitr., Bondartseva, Perevedentseva, Myasnikov et Kovalenko]. Проведенные исследования позволяют характеризовать Panus как хорошо ограниченный род, относящийся к мерулиоидной филогенетической радиации, морфотип которого в основе траметоидный, но несущий поверхностные черты лентиноидных грибов. Его существенными особенностями являются обилие фиброгиф, образующих «перепутанную текстуру» ткани, медленно растущие базидиомы и строго пластинчатый гименофор. По-видимому, такая адаптивная структура была выработана изначально в условиях теплого засушливого климата, и лишь 2 вида (P. conchatus и P. lecomtei) позднее приспособились к обитанию в умеренных широтах. Субстратный спектр этих грибов определяется их нечувствительностью к обводненности субстрата и лучшей способностью к колонизации древесины лиственных пород, поэтому наибольшее количество их находок можно сделать на пнях и крупных остатках основных лесообразующих пород лесов умеренных и теплых широт. Гербарный материал с территории России собран с пней и валежной древесины из родов Betula и Populus. Экотипическая дифференциация рода Panus связана с особенностями колонизированного субстрата. Базиодиомы, появляющиеся сверху пней, характеризуются обычно крепкой центральной ножкой (P. conchatus var. torulosus, P. lecomtei var. semirudis), в то время как на боковых поверхностях валежных стволов развиваются латерально прикрепленные экотипы со слабо развитой ножкой. Оценка ресурсного потенциала представителей этого рода в пределах России должна исходить из наибольшей распространенности P. conchatus и P. lecomtei в Средней полосе России, на Северном Кавказе, Алтае и других районах Южной Сибири, где имеет смысл организовать работы по пополнению штаммового разнообразия этих видов.

\section{Introduction}

This paper continues a taxonomical survey on the genera of Meruliaceae (Polyporales, Basidiomycota) presented in Russian mycobiota (Zmitrovich et al., 2016), and it is devoted to an interesting genus Panus Fr., for a long time considering first within Pleurotaceae, later within Polyporaceae families, but in fact being closely related to the genera Cerrena Gray and Steccherinum Gray of merulioid phylogenetic radiation.

The genus Panus was described by Fries in «Epicrisis Systematis Mycologici seu Synopsis Hymenomycetum» (Fries, 1838) where it was characterized as follows: «Totus fungus carnosocoriaceus, tenax, arescens, contexto fibroso. Lamellae perfectae, tenaces, firmae, inaequales, acie acuta integerrima, saepe venoso-connexae; trama distincta, fibrosa in hymenium radians.
Sporidia alba. Fungi epixyli, difformes laterales, diu persistens». From previously described genus Lentinus Fr. (Fries, 1825) the genus Panus was differentiated by Fries in the following way: «A Lentinis genuinis, quales omnes Europaei, lamellis tenacibus et acie integerrima mox dignoscitur»». Hereby, an entire gills edge in Panus representatives was established as the basic discriminant character of two genera by Fries. In total, 17 species have been distinguished by Fries in the genus Panus, while some of which cannot be correlated with existing herbarium material (below such species will be marked with an interrogation point): Panus farneus Fr. (?), P. cyatniformis (Schaeff.) Fr. [= Neolentinus cyatniformis (Schaeff.) Della Mag. et Trassin.], P. pycnoticus (Klotzsch) Fr. (?), P. torulosus (Pers.) Fr. $[=P$. conchatus (Bull.) Fr.], P. rudis Fr. $[=P$. lecomtei (Fr.) Corner], P. velutinus (Fr.) Sacc., 
P. hirtus Fr. (?), P. foetens Fr. (?), P. dorsalis (Bosc.) Fr. (?), P. stipticus (Bull.) Fr. [= Panellus stipticus (Bull.) P. Karst.], P. farinaceus (Schumach.) Fr. (= Panellus stipticus), P. lunatus Fr. (?), P. copulatus (Ehrenb.) Fr. [= Lentinus copulatus (Ehrenb.) Henn.], P. patellaris Fr. [= Tectella patellaris (Fr.) Murrill], P. delastri Fr. (?), P. lithophilus Fr. (?). Subsequently, the character of gills edge for differentiation Panus from Lentinus was adopted by many agaricologists.

An important episode in Panus taxonomy is related to the works by Singer. In 1951, on the basis of complex similarities between Lentinus, Panus, and Polyporus Fr., this mycologist has united three genera with such genera as Pseudovafolus Pat., Mycobonia Pat., Phyllotopsis E.-J. Gilbert et Donk ex Singer, and Pleurotus (Fr.) P. Kumm. in the family Polyporaceae (Singer, 1951). Considering the Lentinus lepideus (Fr.: Fr.) Fr. as type species for Lentinus (the more correct modern typification is L. crinitus L.), Singer unites all the small-spored species within the genus Panus. Thereafter he has reissued this system three times without essential changing of the concept (Singer, 1962, 1975, 1986).

Corner (1981) has differentiated the genera Lentinus and Panus on the basis of the branching pattern of skeletal hyphae which are organized as dendrites with an inflated axial element in Lentinus and stay unbranched in Panus. In 1983, Pegler has published a monograph on the genus Lentinus, which includes according to this author the Panus-union as a subgenus, but basing on Corner's principles. Within the Lentinus subgenus there are considered species with branched and swollen sclerohyphae, whereas the Panus subgenus unites the species with fibrohyphae (Pegler, 1983).

In the period of molecular taxonomy (Ko, Jung, 1999; Grand, 2004; Larsson, 2007; Lee, Lim, 2010; Miettinen, Larsson, 2011; Zmitrovich, Malysheva, 2013) it was shown that the genus Panus sensu Corner is substantially distant from Lentinus (core Polyporaceae), but closely related to the genus Cerrena Gray (large merulioid phylogenetic radiation). Within the framework of "splitter's approach", even two closely related families Cerrenaceae and Panaceae - have been described (Justo et al., 2017), although we believe that the preservation of the "large Meruliaceae" lies in canvas of more balanced classification of the Polyporales.

Distracting from macromorphology, it can be seen that Cerrena and Panus have much in common: e. g. unbranched fibrohyphae, highly characteristic sclerified elements protruding the hymenium, traditionally called as sclerocystidia or metuloids in the genus Panus, and as pseudocystidia in the genus Cerrena, finally, rather similar basidia and basidiospores. It should be emphasized the absence of any inflated hyphal elements (characteristic feature of representatives of Lentinus and Polyporus s. 1.) in all tissues of representatives of the genus Panus. This feature, as well as rather slow growth of the basidiomata with the formation of solid and often twisting stipe of textura intricata, allows to interpret Panus-like morphotype consider only superficially similar to lentinoid one. It is rather a unique adaptive structure combining true lamellate hymenophore and trametoid growth and tissues organization. Studies on hymenophore development in Panus conchatus, P. lecomtei, and P. fulvus (Hibbett et al., 1993) also confirm this conclusion.

The aim of the present paper is detailed characterization of the genus Panus in Russia, including a modern morphological elaboration, survey of intraspecies polymorphism, substrate preferences and resource potential, considering that some species of this genus are known as promising subject for biomedical research, since produce panepoxidone and isopanepoxidone, substances that has an inhibitory effect on a number of inflammatory chemokines secreted by cancer tissues (Erkel et al., 1996; Shotwell et al., 2000).

\section{Materials and Methods}

The macroscopic descriptions were based on a study of fresh and dried specimens. The materials of the herbaria of Komarov Botanical Institute (St. Petersburg, LE) and Perm State National Research University (PERM) were studied. Microscopic preparations were mounted from dried material in Melzer's solution, $10 \%$ ammoniacal Congo Red and $5 \%$ aqueous solution of $\mathrm{KOH}$, using a LOMO Micmed-6 light microscope. The hyphal system was revealed and described according to updated technique (Zmitrovich et al., 2009). The size of mature spores was measured on 30 spores in distilled water and Melzer's solution.

\section{Results and Discussion}

Meruliaceae Rea, 1922, British Basid.: 620.

$=$ Podoscyphaceae D. A. Reid, 1965, Beih. Nova Hedwigia 18: 43.

$=$ Steccherinaceae Parmasto, 1968, Consp. syst. Cort.: 169.

= Bjerkanderaceae Jülich, 1982, Bibl. Mycol. 85: 356.

= Hapalopilaceae Jülich, 1982, Bibl. Mycol. 85: 370. 
= Hyphodermataceae Jülich, 1982, Bibl. Mycol. 85: 373 .

= Mycorrhaphiaceae Jülich, 1982, Bibl. Mycol. 85: 380 .

= Phanerochaetaceae Jülich, 1982, Bibl. Mycol. 85: 384 .

= Phlebiaceae Jülich, 1982, Bibl. Mycol. 85:

385; Boidin, Mugnier et Canales, Mycotaxon 66: 486, 1998 illeg.

= Irpicaceae Spirin et Zmitr., 2003, Mycena 3: 48.

$=$ Cerrenaceae Miettinen, Justo et Hibbett, 2017, Fungal Biol. 121: 817.

$=$ Panaceae Miettinen, Justo et Hibbett, 2017, Fungal Biol. 121: 817.

Steccherinoideae Parmasto, 1968, Consp. syst. Cort.: 172.

Panus Fr., 1838, Epicr. Syst. Mycol.: 396-397. Nomen conservandum.

= Lentinopanus (Pilát) Pilát, 1941, Ann. Mycol. 39: 72 (type Agaricus conchatus Bull. : Fr.).

Basidiocarp solitary or caespitose, medium-sized to large, slowly growing, tough and persistant, originating from a woody substratum or from sclerotium, of lentioid habitus with gymnocarpic development. Pileus convex, then depressed to umbilicate, tough with dry, with hirsute, fibrillose-squamulose, squamose, or glabrous surface. Margin mostly inrolled, even, or radially ribbed. Hymenophore lamellate. Gills of 2-4 levels, decurrent, rarely furcate, moderately spaced to densely crowded; edge entire. Stipe central to lateral and very reduced, stiff, solid, continuous with the pileus. Context fibrous, toughfleshy to coriaceous, mostly thin. Spore print white to cream colour.

Hyphal system dimitic with unbranched fibrohyphae. Skeletal hyphae (fibrohyphae) predominates in mature basidiocarps, thick-walled, hyaline or yellowish. Generative hyphae thin- to moderately thick-walled, with clamp connections, hyaline. Pileipellis as a repent epicutis of radially parallel hyphae or collapsing trichoderm. Hymenophoral trama irregular, of textura intricata, with sometimes thickening hymenium. Gills-edge usually sterile; as a rule, with emergent pseudocystidia (cheilocystidia). Pleurocystidia absent or present pseudocystidia. Basidia clavate with medial constriction, 4-spored, with a basal clamp. Basidiospores cylindric, or ellipsoid-cylindric to ovoid, hyaline, thin-walled, smooth, lacking both a perisporium and a germpore, inamyloid, acyanophilous.
On dying and dry trees, fallen logs, stumps and large fallen branches of trees and shrubs, presumable angiosprems. Causes a white rot. Worldwide, more abundant in the tropics.

Type species: Agaricus torulosus Pers., 1801, Syn. meth. fung. 2: 475 : Fr., 1821, Syst. Mycol. 1: $181=$ A. conchatus Bull., 1787, Herb. Fr. 7: tab. 298 : Fr., 1821, Syst. Mycol. 1: 181 (selected in Greuter et al. 2000).

Type specimen is deposited in Friesian herbarium of the Uppsala University Museum of Evolution (UPS) (Ryvarden, 1991).

Differential generic suggestions. The genus Lentinus Fr. has a superficial resemblance, but differs by skeleto-binding hyphae with inflated axial segment (all the Panus representatives have uninflated skeletals). The genus Lignomyces R. H. Petersen et Zmitr. is superficially similar too, but differs by monomitic hyphal system with strongly inflated hyphal segments and a dorsal stem attachment (Petersen et al., 2015). Phylogenetically related genus Cymatoderma Jungh. differs by podoscyphoid habitus and the presence of ventricose hymenial gloeocystidia. Phylogenetically related genus Cerrena differs by daedaleoid/trametoid habitus and less elongated (in median) basidiospores.

Ecology and substrata. All the Panus representatives are rather thermophilic, xerotolerant and non-sensitive to substrate watercut, why they are especially often found on large logs and stumps, without allocation of strict substrate specificity. On the other hand, they have not very high enzymatic activity and are generally not adapted to deep decomposition of coniferous wood. This circumstance, as well as their attraction to large-scale tree residues, are the reasons that in zonal biomes they are most often associated to deciduous stand formers (mostly Betula and Populus in the temperate-boreal zone, and Quercus and Fagus in the nemoral zone), although they readily colonize many other trees.

Type of rot. All the Panus representatives cause a white rot. Oxidative enzymes were carefully investigated in Panus lecomtei and $P$. conchatus (Zhang et al., 2006; Zhou et al., 2014). It was shown that purified enzymes of these fungi belong to the laccases family, due to the following observations: 1) the enzyme exhibited a broad substrate pattern, 2) oxygen was used as an oxidative agent, while there was no $\mathrm{H}_{2} \mathrm{O}_{2}$ to initiate the catalytic oxidation, and 3) the determined $\mathrm{N}$-terminal primary structure of the enzyme exhibited a high degree of similarity with the corresponding laccases sequences. 
Secondary metabolites and perspectives in biomedical research. A metabolite of great application value, panepoxidone has been detected in $P$. lecomtei by Erkel group (Erkel et al., 1996). Such metabolite as isopanepoxidone has been isolated from $P$. conchatus by Shotwell et al. (2000), and this substance has a similar effect reducible to the prevention of degradation of inhibiting particles of NF$\kappa \mathrm{B}(\mathrm{I} \kappa \mathrm{B} \alpha)$ that inactivate this transcriptional factor. $\mathrm{NF}-\kappa \mathrm{B}$ chemokine represents the main pro-inflammatory factor, constitutionally associated with cancer progression (Zmitrovich, 2015), therefore such substance as panepoxidone is a prospective subject for biomedical research, whereas the Panus species have a great resource value.

Also, it should be mentioned the production of pink-lilac pigment complexes by both tropical and temperate Panus representatives which were noted already by Miller (1967), but yet were not chemically fractioned.

Specifics of Panus-like morphotype. Basidiocarp development in the Panus representatives was studied by Hibbett et al. (1993), whereas their hyphal differentiation was studied by Zmitrovich et al. (2009). As it was shown, the hymenophore differentiation in Panus involves the periclinal growth of context hyphae below a closed surface palisade of hymenial elements, resulting in a cantharelloid appearance and radiate trama. This pattern is qualitatively different from that in Lentinus s. str., which suggests that lamellae of Panus and Lentinus are not homologous. $P$. conchatus and P. lecomtei basidiocarps have short stipes, whereas $P$. fulvus basidiocarps have an elongate stipe, and develop from a pseudosclerotium. P. conchatus sporocarps developed an ephemeral partial veil that was obliterated during basidiocarp expansion, whereas primordia of $P$. lecomtei are initially gymnocarpic. Analysis of hyphal system of all the tropical representatives of the genus indicates the rigorous dimitism of mature basidiocarp, whereas in $P$. conchatus and $P$. lecomtei the hyphae sclerify slower, while mature basidiocarps include the hyphal elements on different stages of maturation (Zmitrovich et al., 2009). The absence of physalohyphae determining the accelerated growth of agaricoid basidiocarps makes the growth of Panus representatives more monotonous and slow, what, in combination with its hyphal structure, brings Panus-like morphotype together with trametoid one. However, the hymenophore of Panus is a classical lamellate that indicates a surprising convergence among agaricomycetes.
Tropical species. As a rather specific adaptive type, the genus Panus was generated by arid and warm climates of the planet, where the main species diversity of the genus is concentrated. The following species, common in various tropical regions, are most known.

Panus ciliatus (Lév.) T. W. May et A. E. Wood, 1995, Mycotaxon 54: 148 (Bas.: Lentinus ciliatus Lév., 1844; Syn.: L. melanophyllus Lév., 1844; L. setiger Lév., 1844; L. echinopus Lév., 1846; L. braccatus Lév. in Zolling., 1854; L. dichrous Lév. In Zolling., 1854; L. zonifer Berk. et Broome, 1873; L. egregious Massee, 1910; Panus brunneipes Corner, 1981).

P. fasciatus (Berk.) Singer, 1962, Agaricales mod. Tax. $2^{\text {nd }}$ ed.: 172 (Bas.: Lentinus fasciatus Berk., 1840; Syn.: L. dealbatus Fr. in Lehmann, 1847; L. fuscopurpureus Kalchbr., 1880; L. holopogonius Berk. ex Cooke, 1892; L. terrestris Lloyd, 1925).

P. hookerianus (Berk.) T. W. May et A. E. Wood, 1995, Mycotaxon 54: 148 (Bas.: Lentinus hookerianus Berk., 1851).

P. similis (Berk. et Broome) T. W. May et A. E. Wood, 1995, Mycotaxon 54: 148 (Bas.: Lentinus similis Berk. et Broome, 1873; Syn.: L. velulinus Fr. var. africanus P. Henn. in Engler, 1893; L. erringtohnii Pat., 1900; L. samurensis Pilát, 1941).

P. strigellus (Berk.) Chardon et Toro, 1934, Monogr. Univ. Porto Rico Ser. B 2: 315 (Bas.: Lentinus strigellus Berk., 1868; Syn.: Panus guaraniticus Speg., 1883; Lentinus crispus Pat., 1889; L. tubarius Pat., 1899; Pocillaria palmeri Earle, 1906; Lentinus subglaber Lloyd, 1917).

P. tephroleucus (Mont.) T. W. May et A. E. Wood, 1995, Mycotaxon 54: 148 (Bas.: Lentinus tephroleucus Mont., 1851; Syn.: L. leprieurii Mont., 1854; L. siparius Berk. et M. A. Curtis, 1868; L. dentatus Bres., 1925).

P. velutinus (Fr.) Overh., 1930, J. Dept Agric. Porto Rico 14: 353 non Fr., 1838 (Bas.: Lentinus velutinus Fr., 1830; Syn.: Lentinus fulvus Berk., 1842; L. coelopus Lév., 1846; L. nepalensis Berk., 1854; L. blepharodes Berk. et M. A. Curtis, 1868; L. fastuosus Kalchbr. et MacOwan, 1881; L. fallax Speg., 1883; L. castaneus Ellis et Macbr., 1896; L. holumbrinus De Seynes, 1897; L. fissus P. Henn., 1897; L. natalensis Van der Byl., 1924; L. thomensis Coutinho, 1925; L. pseudociliatus Raithelhuber, 1974).

Provisional position: Lentinus hirtiformis Murrill, N. Am. Fl. 9: 293, 1915; L. courtetianus Har. et Pat., Bull. Mus. Hist. Nat. Paris 15: 88, 1909 (Zmitrovich, Malysheva, 2013). 
Species irradiating into temperate zones. Two species, being widespread in subtropical and tropical regions, have been irradiated into temperate zones of the northern and partly southern hemispheres. They are characterized by less xeromorphic habitus in comparison to strictly tropical species and demonstrate pseudodimiticism even at rather advanced developmental stages. Both species are distributed throughout Russia: P. conchatus and P. lecomtei (see below).

\section{Key to temperate species}

1. Upperside matt-subtomentose, soon glabrescent and cracking with formation of fine appressed squamules; basidia 20-35 $\times 4.5-6 \mu \mathrm{m}$; basidiospores 5-6.5 $\times 2.2-3.5 \mu \mathrm{m}$, ellipsoid-cylindrical

1. P. conchatus

- Upperside tomentose, then strigose; basidia 15-20 × 3.5-5 $\mu \mathrm{m}$; basidiospores 4.5-6 × 2.5-3.7 $\mu \mathrm{m}$, mostly ovoid

2. P. lecomtei

1. Panus conchatus (Bull.) Fr., 1838, Epicr. Syst. Mycol.: 396.

$\equiv$ Agaricus conchatus Bull., 1787, Herb. Fr. 7: tab. 298 : Fr., 1821, Syst. Mycol. 1: 181.

$=A$. carneotomentosus L., 1753, Sp. pl. 2: 1171 .

$=$ A. flabelliformis Schaeff., 1774, Fung. bavar. palat. nasc. 4: 20.

$=$ A. carneotomentosus Batsch, 1783, Elench. fung.: 89 .

$=$ A. mesentericus Batsch, 1783, Elench. fung. (Halle): 91.

$=$ A. carnosus Bolton, 1792, Hist. fung. Halifax, App. 3: 146. 1410.

$=$ A. flabellatus J. F. Gmel., 1792, Syst. Nat. 2(2):

$=A$. inconstans Pers., 1800, Comm. Schaeff. Icon. Pict.: 17. 475.

$=$ A. fornicatus Pers., 1801, Syn. meth. fung. 2: 475.

$=$ A. torulosus Pers., 1801, Syn. meth. fung. 2:

= Pleuropus fornicatus Gray, 1821, Nat. Arr. Brit. Pl. 1: 615.

= Panus monticola Berk., 1851, Hooker's J. Bot. Kew Gard. Misc. 3: 46.

$=$ P. vaporarius Bagl., 1865, Comm. Soc. crittog. Ital. 2(fasc. 2): 264.

$=$ Lentinus percomis Berk. et Broome, 1875, J. Linn. Soc., Bot. 14(no. 73): 42. 141.

$=$ L. bresadolae Schulzer, 1885, Hedwigia 24(4):

= Panus flabelliformis Quél., 1888, Fl. Mycol. France (Paris): 325.
$=$ Lentinus obconicus Peck, 1906, Bull. Torrey bot. Club 33(4): 215.

I c o n .: Malkovský (1932: fig. 1-4, ut Panus flabelliformis); Phillips (1981: fig. 267d); Pegler (1983: fig. 35); Hansen, Knudsen (1992: fig. 2 ut Lentinus conchatus); Courtecuisse, Duhem (1994: fig. 135); Zmitrovich et al. (2004: fig. 25); Knudsen, Vesterholt (2008: 73D).

Basidiocarp solitary or caespitose, mediumsized, originating from a woody substratum, of lentioid habitus. Pileus $1.5-15 \mathrm{~cm}$ diam., tough fleshy, then coriaceous, applanate or depressed, often conchoid or cyathiform. Upperside pinkish-lilac to vinaceous-purple when young, then fading from the centre to pale-clay, ochraceous-brown or cinnamon, matt-subtomentose, soon glabrescent, finally smooth and shiny or cracking at the centre to form indefinite, appressed squamules. Margin sharp, thin, inrolling, slightly undulate or lobed, pruinose when young, occasionally strigose. Stipe central to lateral, $0.5-4 \times 0.5-3 \mathrm{~cm}$, cylindric to bulbous, sometimes tapering at the base, solid; surface initially tinted violaceous then fading to leave a pale grey, velutinate to short strigose tomentum, pubescent at the base, finally glabrous. Context tough fleshy, then coriaceous, $1-15 \mathrm{~mm}$ thick at the disk, ivory-white. Hymenophore lamellate. Gills deeply decurrent with a ridge extending down the stipe, often slightly anastomosing over the stipe surface, at first violaceous or purplish then cream colour, pinkish towards the edge; initially very narrow but eventually becoming broader, $2-4.5 \mathrm{~mm}$ wide, very crowded, with lamellulae of four lengths; edge entire (Fig. 1).

Hyphal system dimitic with rather prolonged pseudodimitic stage. Generative hyphae 2-4.5 $\mu \mathrm{m}$ diam., non-inflating, hyaline, thin-walled, branched, with large clamp connections. Skeletal hyphae 2-5 $\mu \mathrm{m}$ diam., unbranched, sinuose, hyaline, thick-walled, the pseudoskeletal hyphae of the same diameter, with clamp connections, and refractive contents predominate in young basidiocarps. Pileipellis an epicutis, 45-90 $\mu \mathrm{m}$ thick, of repent, radially parallel generative hyphae 3-5 $\mu \mathrm{m}$ diam. with a golden-brown wall. Hymenophoral trama irregular, hyaline, of radiate construction, similar in structure to the context. Gills-edge sterile, with conspicuous, crowded, clavate to sublageniform cheilocystidia 24-60 × 7-16 $\mu \mathrm{m}$, hyaline, thin- to thick-walled. Pleurocystidia (pseudocystidia) abundant, 25-70 × 5-10(12) $\mu \mathrm{m}$, narrowly clavate, often sinuous and constricted, thick-walled, originating deep in the subhymenial layer and projecting 5-20 $\mu \mathrm{m}$ above the basidia. Basidia 20-35 × 4.5-6 $\mu \mathrm{m}$, 
clavate-cylindrical, 4-spored, with a basal clamp. Basidiospores 5-6.5 × 2.2-3.5 $\mu \mathrm{m}$, ellipsoid-cylindrical, hyaline with few contents, thin-walled.

On dying trees, fallen logs and branches, stumps of many hardwoods, causing a white rot.

Substrata: on many hardwoods, especially Betula spp. and Populus tremula, rarely on conifers (Pinus sylvestris).

Cultural characteristics: Hibbett et al. (1993); Johnson, Methven (1994); Grand (2004).

General distribution: EUROPE (Austria, Belarus, Belgium, Bulgaria, Denmark, Estonia, Finland, France, Germany, Latvia, Lithuania, Norway, Russia, Scotland, Spain, Sweden, Ukraine); AFRICA (Ethiopia); ASIA (Armenia, Georgia, Japan, Korea, Russia); NORTH AMERICA (Canada, Mexico, USA), CENTRAL AMERICA (Costa Rica); SOUTH AMERICA (Equador); AUSTRALIA and OCEANIA (Australia) (Pegler, 1983; Panus conchatus.., 2018).

Distribution in Russia: see Table 1.
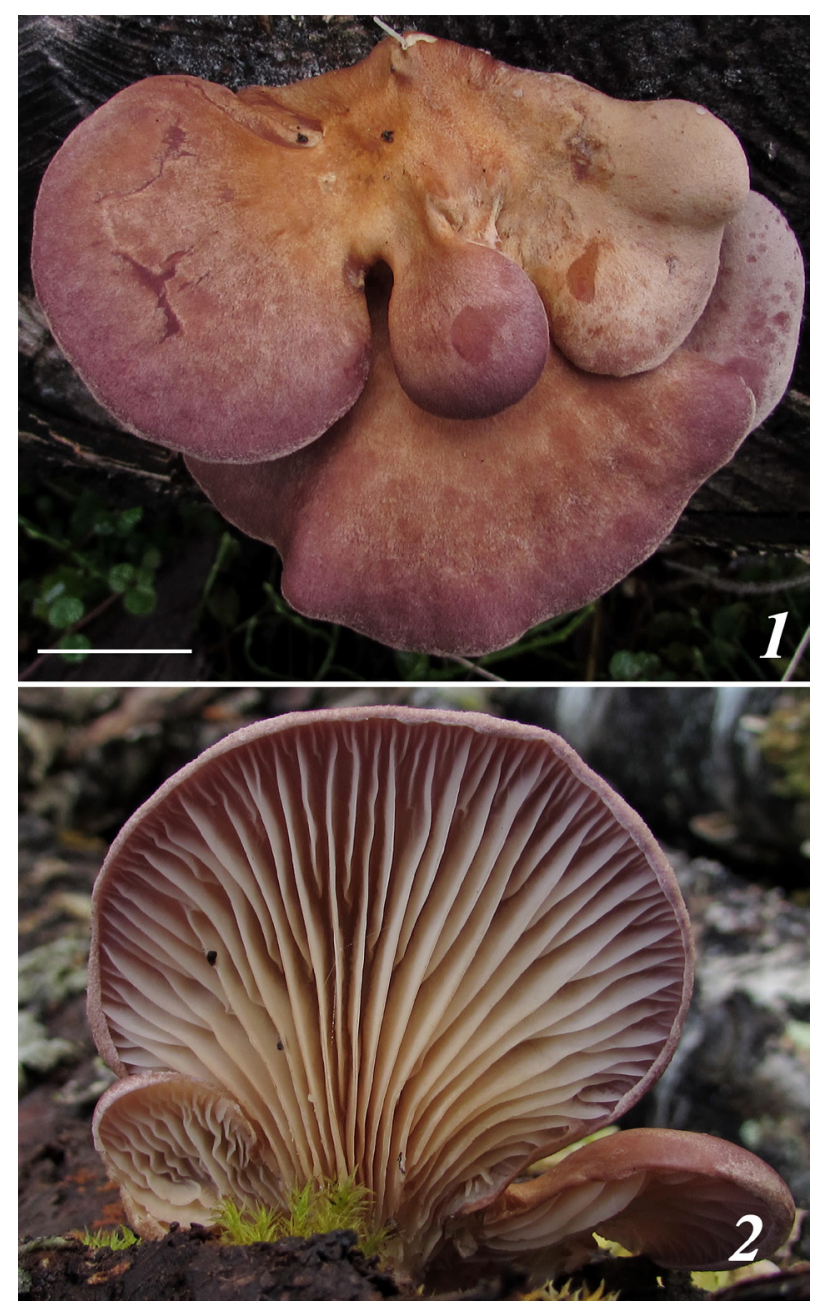

Fig. 1. The most typical laterally attached morphotype of Panus conchatus (Kalinovskaya 4552M/12): 1 - an upperside view; 2 - a hymenophore. Scale bar $-1 \mathrm{~cm}$.
Exsiccates examined. Panus torulosus: "Sweden, Bohuslan, Uddevalla, Sarven Lake, on stump of Betula sp., X 1947. S. Woldmar LE 3722 (S. Lundell et J. A. Nannfeldt. Fungi exsiccati Suecici praesertim Upsalienses, N 1771)". - "Sweden, Västergötland, Göteborg, Naturparken, on stump of Betula sp., 20 IX 1960. F. Karlvall LE 3723 (S. Lundell et J. A. Nannfeldt. Fungi exsiccati Suecici praesertim Upsalienses, N 2865)". - "Sweden, Småland, Femsjö parish, on stump of Betula sp., 28 IX 1959. F. Karlvall LE 3721 (S. Lundell et J. A. Nannfeldt. Fungi exsiccati Suecici praesertim Upsalienses, N 2866)". - "Russia, Khabarovsk Region, Ragozhino vicinities, on Quercus sp., 03 VI 1910. M. Korotkiy (M. Korotkiy. Museum Botanicum Academiae Scientiarum Petropolitanae, N 73)". - "England, 15 III 1989. F. B. Delange LE 24071, LE 24074 (R. B. G. K. Richmond. Herbarium path/mixed debris England, N 73). "USSR, Bashkortostan Republic, Bashkirsky Reserve, Drozdov Log vicinities, on stump of Pinus sylvestris, VIII 1948. E. A. Selivanova-Gorodkova LE 3703 (E. A. Selivanova-Gorodkova. Plantae australiuralenses, N 459)".

\section{Association with Trametes multicolor.} According to our observations made on the Karelian Isthmus clear cuttings, Panus conchatus often settles on stumps, primarily colonized by Trametes multicolor (Schaeff.) Jülich (Fig. 2). Within ten records made for Betula stumps on the Karelian Isthmus clear cuttings, seven ones have contained an indication of the joint presence of Panus conchatus and Trametes multicolor. The latter species is an active producer of laccase and is characterized by high growth rate (Zmitrovich et al., 2017). Apparently, their primary delignification and moistening of wood by T. multicolor creates a niche for Panus conchatus, carrying out a deeper substrate delignification. The pair in question certainly echoes with another pair, Antrodiella pallescens/Fomes

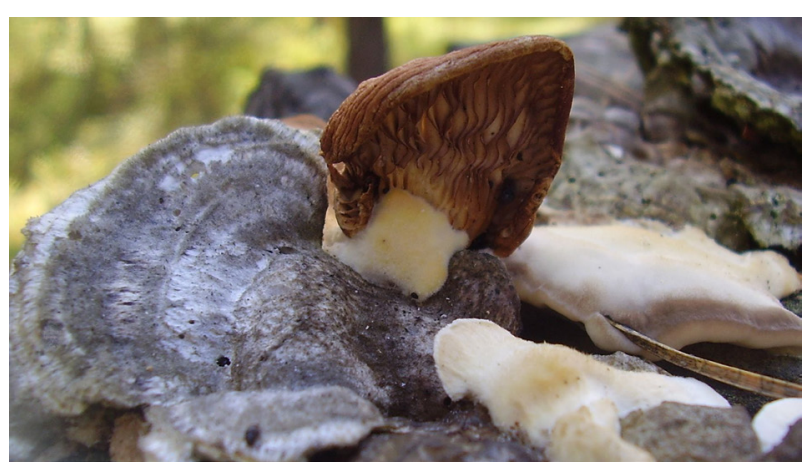

Fig. 2. Association of Panus conchatus with Trametes multicolor-coll. (Zmitrovich 2014-12). 
fomentarius, described for dead wood in boreal forests (Spirin, 2002).

Nomenclature. Two names sanctioned by Fries (1821) were considered in the literature as a fit basionyms of this species, Agaricus conchatus (Bulliard, 1787) and A. torulosus (Persoon, 1801). Since both names are sanctioned by Fries and there is no any doubt in their synonymy, the combination based on A. conchatus name, i. e. Panus conchatus (Fries, 1838), has a priority.

Intraspecific variability. As a neutral type of this species (P. conchatus var. conchatus) the more or less lateral ecotype with conchiform pileus and rather dark wine-red to lilac-brown surface is considered by default. Two main deviations from such neutral type were described: 1) the chromatic one, characterized by light-colored (red or clayyellow), usually conchiform pilei (P. conchatus var. inconstans) and 2) the growth one, characterized by entral (often bulbous) stipe, funnel-shaped cap and strongly inrolled margin ( $P$. conchatus var. torulosus).

Panus conchatus var. inconstans (Pers.) Zmitr., Bondartseva, Perevedentseva, Myasnikov et Kovalenko, comb. nov. (MB 824338). - Basionym: Agaricus inconstans Pers., 1800, Comm. Schaeff. Icon. Pict.: 17.

$=A$. conchatus var. carneotomentosus Fr., 1832, Syst. Mycol. (Index): 11.

Persoon (1800) has characterized this taxon as follows: «Subcespitosus, pileo carnoso tenaci depresso integro, aut dimidiato lobato flexuoso, ex alutaceo subrufescente, lamellis subramosis basi crispis albis subrutilesque, stipite brevi sublaterali».

Ic on.: Malkovský (1932: fig. 5, ut Panus flabelliformis).

From type variety differs by clay-buff, carneous of rufescent color of the upperside. Basidiocarps of conchoid appearance, the stipe often reduced and then the hymenophore is subporoid at the base. The microstructures vary as in a neutral type.

Panus conchatus var. torulosus (Pers.) Zmitr., Bondartseva, Perevedentseva, Myasnikov et Kovalenko, comb. nov. (MB 824339). - Basionym: Agaricus torulosus Pers., 1801, Syn. meth. fung. 2: 475.

I c o n .: Malkovský (1932: fig. 2, 3, 6 ut Panus flabelliformis).

From type variety differs by funnel-shaped basidiocarps on a central stipe, often with bulbous base, and inrolled undulating margin. The microstructures vary as in a neutral type (Fig. 3).
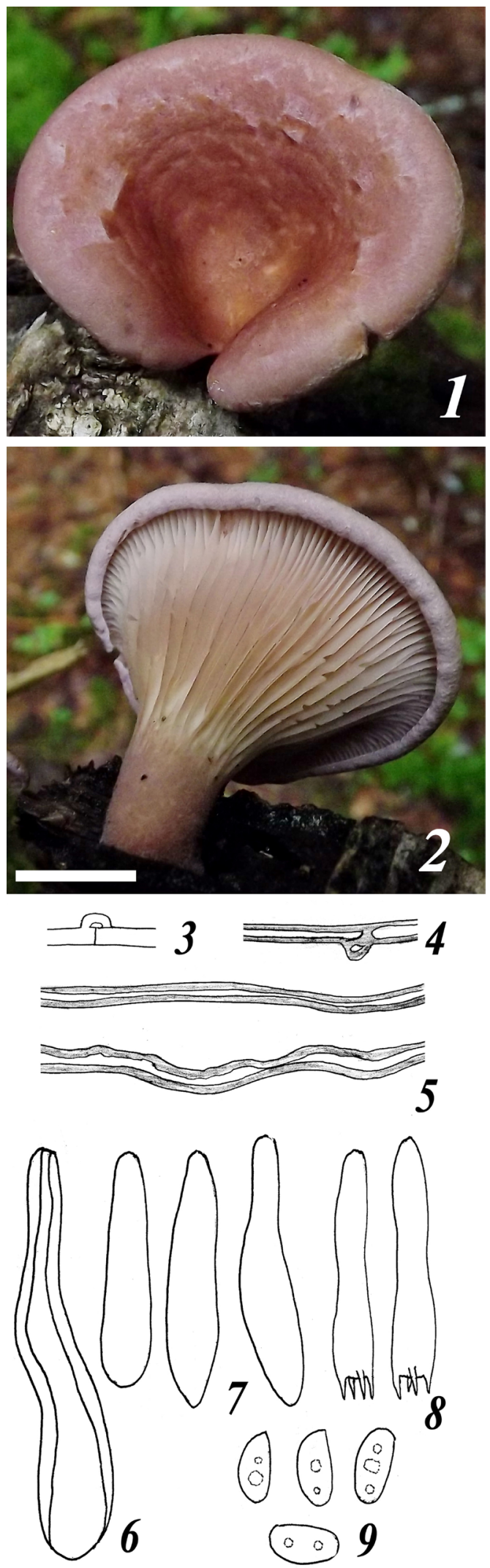

Fig. 3. Panus conchatus var. torulosus (Kalinovskaya 3850M/15): 1 - an upperside view; 2 - a hymenophore; 3 - generative hypha; 4 - pseudoskeletal hypha; 5 - fibrohyphae; 6 - pseudocystidium; 7 - cheilocystidia; 8 basidia; 9 - basidiospores. Scale bars: 1,2-1 cm, 3-9$10 \mu \mathrm{m}$. 
2. Panus lecomtei (Fr.) Corner, 1981, Beih. Nova Hedwigia 69: 90.

$\equiv$ Lentinus lecomtei Fr., 1825, Syst. Orb. Veg. 1: 77.

= Agaricus strigopus Pers. in GaudichaudBeaupré in Freycinet, 1827, Voy. Uranie., Bot.: 167. $=A$. hirtus Secr., 1833, Mycogr. Suisse 2: 452.

= A. macrosporus Mont., 1837, Annls Sci. Nat., Bot., sér. 2 8: 370.

= Panus rudis Fr., 1838, Epicr. Syst. Mycol.: 398.

= Lentinus capronatus Fr., 1838, Epicr. Syst. Mycol.: 389.

$=A$. sainsonii Lév. in Demidov, 1842, Voyage dans la Russie Meridionale et la Crimeé, par la Hongrie, la Valachie et la Moldavie 2: 85.

= Lentinus chaetophorus Lév., 1844, Annls Sci. Nat. Bot. 2: 177.

$=$ L. melanophyllus Lév., 1844, Annls Sci. Nat. Bot. 2: 175.

= Panus lamyanus Mont., 1856, Syll. gen. sp. crypt.: 147.

$=P$. hoffmannii Fr. in Hoffmann, 1867, Icon. Anal. Fung., Abbild. Beschr. Pilz. 1(4): 94.

$=$ Lentinus sparsibarbis Berk. et M. A. Curtis, 1869, J. Linn. Soc., Bot. 10(no. 45): 301.

$=$ L. substrigosus Henn. et Shirai in Hennings, 1900, Bot. Jb. 28(3): 270.

= Panus semirudis Singer, 1936, Beih. Botan. Centralbl. B 56: 142.

$=P$. fragilis O. K. Mill., 1965, Mycologia 57(6): 943.

$=P$. neostrigosus Drechsler-Santos et Wartchow, 2012, J. Torrey bot. Soc. 139(4): 438.

I c on .: Malkovský (1932: fig. 10-12, ut P. rudis); Zerova (1974: tab. 90, 1 ut P. rudis); Pegler (1983: fig. 31, ut Lentinus strigosus); Zmitrovich et al. (2004: Tab. 4, $a, b$ ut Panus rudis); Bulakh (2015: fig. 418).

Basidiocarp solitary or caespitose, mediumsized, originating from a woody substratum, of lentioid habitus. Pileus $1.5-12 \mathrm{~cm}$ diam., tough fleshy, then coriaceous, convex, then depressed to infundibuliform, or laterally attached and flabelliform to spathulate. Upperside ivory-white to stramineous with prominent lilac or vinaceous tints, fading pale-ochraceous or grayish-brown, at first tomentose, then strigose (hairs 1-2 mm long), without a clear zonation. Margin thin, inrolling, slightly undulate or lobed, strongly strigose. Stipe eccentric to lateral, $0.5-3.8 \times 0.3-1.5 \mathrm{~cm}$, cylindric to bulbous, solid, sometimes reduced; surface concolorous with the pileus, tomentose-strigose. Context tough fleshy, then coriaceous, 1-7 mm thick at the disk, ivory-white. Hymenophore lamellate. Gills deeply decurrent, ivory-white to ochraceous-buff, sometimes with violaceous tints; initially very narrow but eventually becoming broader, 1-2 mm wide, very crowded, with lamellulae of four lengths; edge entire (Fig. 4).

Hyphal system dimitic with expressed pseudodimitic stage. Generative hyphae 2-4 $\mu \mathrm{m}$ diam., non-inflating, hyaline, thin-walled, branched, with large clamp connections. Skeletal hyphae 2-7.5 $\mu \mathrm{m}$ diam., unbranched, sinuose, hyaline, thick-walled to subsolid, the pseudoskeletal hyphae of the same diameter, bearing clamp connections and refractive contents, are abundant in young basidiocarps. Pileipellis a trichodermal epicutis, 25$45 \mu \mathrm{m}$ thick, of repent, radially parallel generative hyphae 3-7.5 $\mu \mathrm{m}$ diam. with a golden-brown wall. Hymenophoral trama irregular, hyaline, of radiate construction, similar in structure to the context.

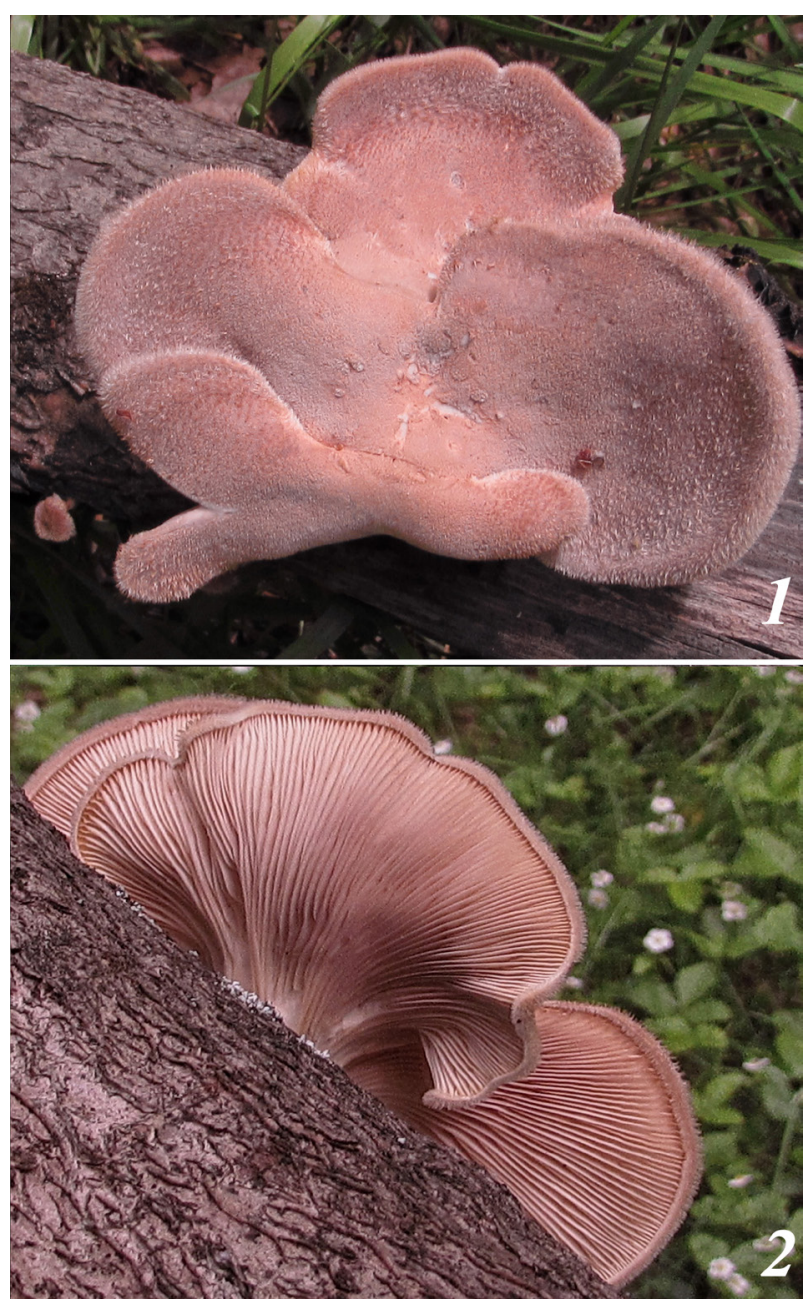

Fig. 4. The most typical laterally attached morphotype of Panus lecomtei (Myasnikov 4472A/15): 1 an upperside view; 2 - a hymenophore. Scale bar - 1 $\mathrm{cm}$. 
Gills-edge sterile, with conspicuous, crowded, clavate to sublageniform cheilocystidia $18-35 \times 4-6$ $\mu \mathrm{m}$, hyaline, thin- to thick-walled. Pleurocystidia (pseudocystidia) abundant, 25-55 × 9-13 $\mu \mathrm{m}$, narrowly clavate, often sinuous and constricted, thick-walled, originating deep in the subhymenial layer and projecting up to $40 \mu \mathrm{m}$ above the basidia. Basidia $15-20 \times 3.5-5 \mu \mathrm{m}$, clavate-cylindrical, 4-spored, with a basal clamp. Basidiospores 4.5-6× 2.5-3.7 $\mu \mathrm{m}$, ovoid to ellipsoid-cylindrical, hyaline with few contents, thin-walled.

On dying trees, fallen logs and stumps, causing a white rot.

Substrata: On many hardwoods, especially Carpinus betulus, Betula spp., Fagus sylvatica, Quercus spp., rarely on conifers (Larix spp.).

Cultural characteristics: Hibbett et al. (1993); Grand (2004); Vargas-Isla, Ishikawa (2008); Petre, Tănase (2013).

General distribution: EUROPE (Bulgaria, Estonia, France, Germany, Hungary, Portugal, Romania, Russia, Serbia, Slovakia, Slovenia, Spain, Ukraine); AFRICA (Madagascar, Mayotte, Uganda, Zaire); ASIA [India, Iran, Japan, Malaysia, Myanmar (Burma), Nepal, Pakistan, Philippines, Russia, Sri Lanka, Taiwan, Thailand, Turkey]; NORTH AMERICA (Canada, Mexico, USA), CENTRAL AMERICA (Costa Rica, Cuba, Guatemala, Honduras, Nicaragua, Panama, Puerto Rico); SOUTH AMERICA (Argentina, Brazil, Colombia, Guiana, Paraguay, Peru, Venezuela); AUSTRALIA and OCEANIA (Galapagos, Norfolk Island, Papua New Guinea, Australia) (Pegler, 1983; Panus neostrigosus .., 2018).

Distribution in Russia: see Table 2.

Exsiccates examined. Agaricus sainsonii: "Russia, 1842. A. Demidoff LE 5848 (J. Leveillé. Voyage dans la Russie Meridionale et la Crimeé, N 85)". - Lentinus lecomtei: "USA, Ohio, VII 1883. W. A. Kellermann LE 5849 (RabenhorstWinter. Fungi Europaei, N 2940)". - Panus rudis: "Austria, trunk of Fagus sylvaticus. P. P. Strasser LE 5854 (P. P. Strasser. Kryptogamae exsiccatae, N 1422)". - "Georgia, Tiflis Hortus Botanicus, $12 \mathrm{X}$ 1923. G. Woronow LE 208198 (G. Woronow. Fungi Caucasici, N 2127)". - "Russia, Tomsk Region, on stump of Betula sp., 3 III 1926. Lavrov LE 5803 (A. A. Jaczewski. Ex Herbario Instituti Mycologici et Phytopathologici, N 81)". - "Austria, Salzburg, on fallen trunk of Fagus sylvatica, 1914 C. Keissler LE 5851 (C. Keissler. Kryptogamae exsiccatae, N 1422)". - "Baton Range, 23 II 1960. B. Lowy LE 5845 (B. Lowy. Ex Mycological Herbarium of Lou- isiana State University)". - "Russia, Bashkortostan Republic, Bashkirsky reserve, Drozdov Log vicinities, on stump of Betula sp., 8 IX 1946 E. A. Selivanova-Gorodkova LE 5838 (E. A. Selivanova-Gorodkova. Plantae australiuralenses, N 2427)." - "Russia, Bashkortostan Republic, Bashkirsky reserve, Drozdov Log vicinities, on stump of Betula sp., 8 IX 1946 E. A. Selivanova-Gorodkova LE 5834 (E. A. Selivanova-Gorodkova. Plantae australiuralenses, N 2429). - Panus sainsonii: "Austria, Salzburg, IX 1868 Dr. Sauter LE 5855 (Rabenhorst-Winter. Fungi Europaei, N 1207)". - "Austria, Salzburg, on fallen trunk of Fagus. Dr. Sauter LE 5850 (F. Thümen. Fungi austriaci, N 212)".

Nomenclature. Two names in application to this peculiar species persisted in the literature for a long time, Lentinus strigosus and Panus rudis. Since, as it was shown, this species does not belong to the Lentinus s. str. (Zmitrovich, Malysheva, 2013; Zmitrovich, Kovalenko, 2016), it became necessary a nomenclatural adaptation of species name within the Panus. Because of the name P. strigosus Berk. et M. A. Curtis was preoccupied by Berkeley and Curtis (1859) in application to another species, the name $P$. rudis (Fries, 1838) continued to be persisting. Drechsler-Santos et al. (2012) proposed new name $P$. neostrigosus without any nomenclature analysis, and this name was taken as a basis for GBIF (Panus neostrigosus ... 2018). At the same time, Corner (1981) already made a combination $P$. lecomtei, basing on the description by Fries Lentinus lecomtei in his earlier work (Fries, 1825).

Intraspecific variability. As a neutral type of Panus lecomtei (P. lecomtei var. lecomtei), the ecotype having small eccentric to lateral minute and often spalled stipe is considered by default. However, the stipe shape and size are variable. The stipe can be either central - minute, with a bulbous base (P. lecomtei var. semirudis), or strongly elongated (P. lecomtei var. stipitata).

Panus lecomtei var. semirudis (Singer) Zmitr., Bondartseva, Perevedentseva, Myasnikov et Kovalenko, comb. nov. (MB 824340). - Basionym: Panus semirudis Singer, 1936, Beih. Botan. Centralbl., Abt. B 56: 142.

From type variety is distinguished by short, but strong and often bulbous stipe of central or subcentral position. Upperside is moderately strigose to glabrous at the center, color usually fading to ochraceous-brown. The microstructures vary as in a neutral type (Fig. 5). 
Panus lecomtei var. stipitatus (Malk.) Zmitr., Bondartseva, Perevedentseva, Myasnikov et Kovalenko, comb. nov. (MB 824341). - Basionym: Panus rudis f. stipitata Malk., 1932, Annls mycol. 30(1/2): 40.

I c o n .: Malkovský (1932: fig. 12, ut Panus rudis f. stipitata).

From type variety is distinguished by long lateral or eccentric stipe and spathulate pilei. Upperside is strongly strigose, color usually fading to cinnamon. The microstructures vary as in a neutral type (Fig. 6).
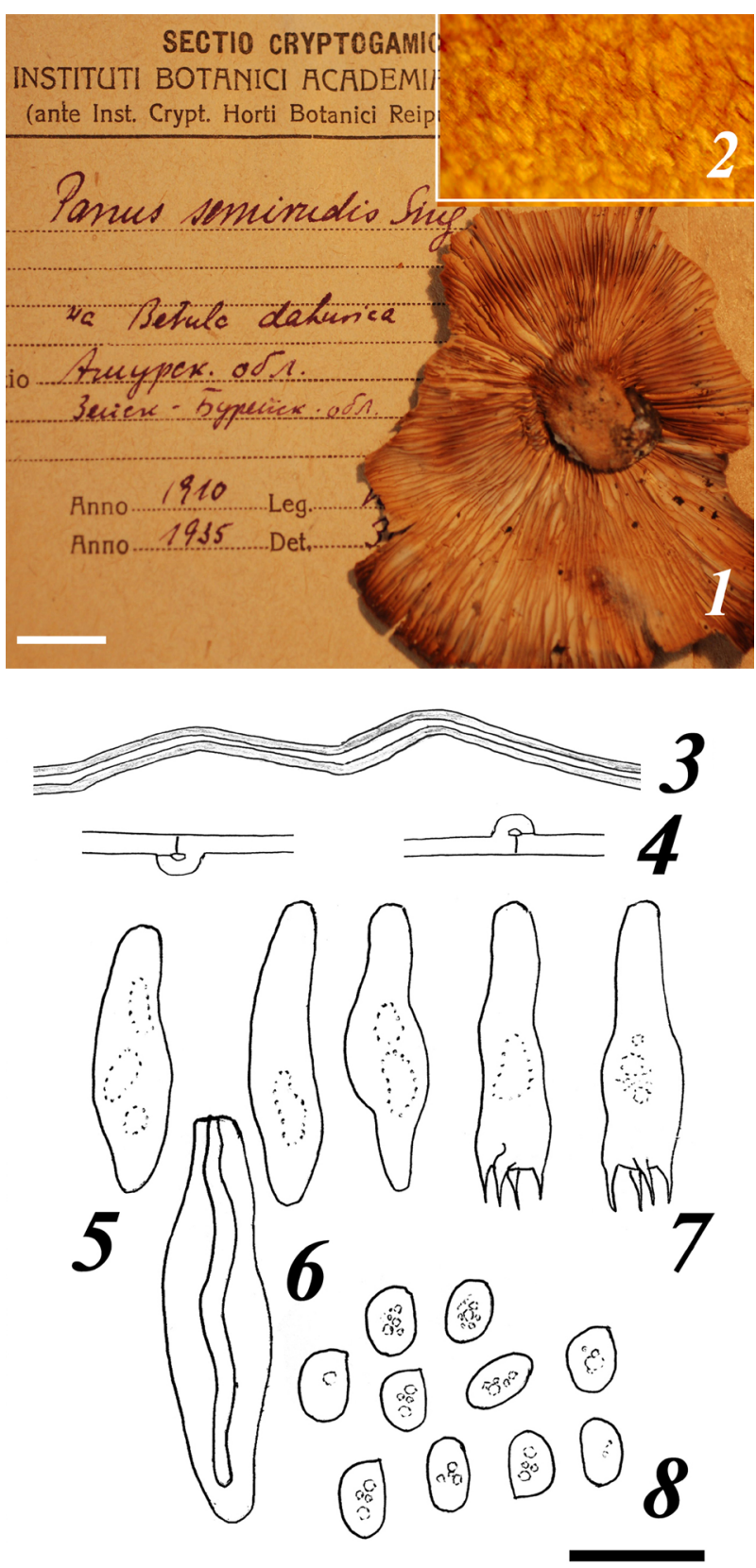

Fig. 5. Panus lecomtei var. semirudis (LE 3660): 1 - hymenophore; 2 - upperside view; 3 - fibrohypha; 4 - generative hyphae; 5 - cheilocystidia; 6 - pseudocystidium; 7 - basidia; 8 - basidiospores. Scale bars: $1,2-1 \mathrm{~cm}$, $3-8-10 \mu \mathrm{m}$.
The problem of Lentinus martianoffianus. This problematic species was described by Thümen (1877) with reference to Kalchbrenner, and its authentic material kept in Kew Herbarium (K). There is a single specimen, collected on Populus balsamifera by Martianoff near Minussinsk in 1880 and distributed within exsiccate series by Thümen (Fung. Exot. Dec. 21).

The Kew material was studied by Pegler (1983) and described as follows: "Imbricate. Pileus laterally attached, 3-5 cm diam., thin, coriaceous, irregularly flabelliform, depressed; surface pale yellowish rufous, uniformly velutinate-strigose becoming hispid towards the margin; margin irregular, deeply lobed, faintly sulcate, densely ciliate with hair-like squamules, 1-2 mm long. Lamellae decurrent, pallid, narrow, about $1 \mathrm{~mm}$ wide, very crowded, with lamellulae of three lengths; edge entire. Stipe lateral, $1-1.5 \mathrm{~cm} \times 8-12 \mathrm{~mm}$, short, cylindric or compressed, solid; surface concolorous with the pileus, densely strigose, glabrescent. Context up to $2 \mathrm{~cm}$
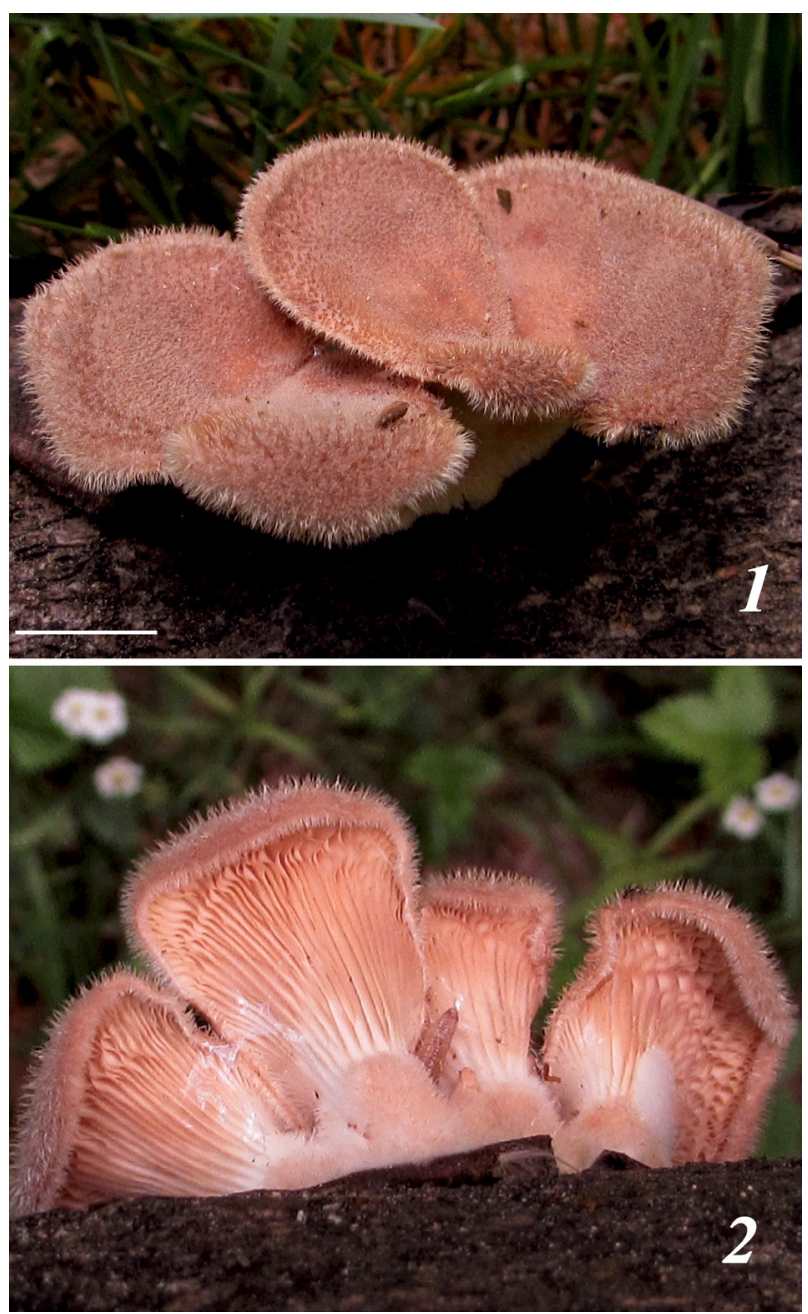

Fig. 6. Panus lecomtei var. stipitatus (Myasnikov 4350A/16): 1 - upperside view; 2 - hymenophore. Scale bar $-1 \mathrm{~cm}$. 
thick at the base, very thin over the hymenophore, white, consisting of a dimitic hyphal system with skeletal hyphae. Generative hyphae $2-5 \mu \mathrm{m}$ diam., not inflating, hyaline, branched, thin-walled or occasionally with a slightly thickened wall, and clamp-connexions. Skeletal hyphae 2-6 $\mu \mathrm{m}$ diam., unbranched, hyaline, with a thickened wall (up to 2 $\mu \mathrm{m}$ ) and a narrow lumen, intercalary and terminal in origin, finally tapering to an obtusely rounded apex. Spores $4.7-6.2 \times 1.7-2.5 \mu \mathrm{m}, \mathrm{Q}=2.37$, narrowly cylindric, at times arcuate, hyaline, thin-walled, with few contents. Basidia 16-22 × 4.5-5.5 $\mu \mathrm{m}$, clavate, bearing four sterigmata. Lamella-edge sterile, forming a narrow zone of small, inconspicuous cheilocystidia, together with scattered metuloids. Cheilocystidia $16-24 \times 3.5 \times 5 \mu \mathrm{m}$, basidioid, sinuous fusoid, often constricted, with a rounded apex, hyaline, thin-walled. Metuloids scattered to numerous, on both sides and edge of lamellae, 26-45 $\times$ 7-12 $\mu \mathrm{m}$, inflated clavate to fusoid-submucronate, usually with a thickened wall $(1-2.5 \mu \mathrm{m})$ and resinous, yellowish brown contents, projecting to 25 $\mu \mathrm{m}$ beyond the basidia, sometimes surrounded by a sheath of thin-walled, generative hyphae, $2-5 \mu \mathrm{m}$ diam. Hymenophoral trama irregular, hyaline, of radiate construction, comprising mostly of generative hyphae. Subhymenial layer well developed, 14-20 $\mu \mathrm{m}$ wide, tightly interwoven. Pileipellis a disrupted and irregular trichodermial palisade, forming fascicles of unbranched, sclerified generative hyphae, 4-6 $\mu \mathrm{m}$ diam., with an obtusely rounded apex" (Pegler, 1983).

Since the molecular testing of any Kew material is prohibited, only the morphological description may be considered on, which unambiguously indicates the close relationships of this taxon with $\mathrm{Pa}$ nus lecomtei-coll. Only basidiospores are something diverse, since are not ovoid, but rather ellipsoidalcylindrical. Malkovský (1932) has considered Lentinus martianoffianus as a synonym of Panus rudis, whereas Pegler (1983) has abstained from synonymization procedure. In any case, this taxon belongs to the genus Panus, although there have been attempted to associate this name with the Lentinus

Table 1

Herbarium data on distribution of Panus conchatus over Russian territory and its substrate preferences

\begin{tabular}{|c|c|c|c|c|}
\hline Region & Substrata & Date of collection & Collector & $\begin{array}{c}\text { Herbarium } \\
\text { numbers }\end{array}$ \\
\hline \multicolumn{5}{|c|}{ European part } \\
\hline Karelia Republic & Betula pubescens & $08 \times 1950$ & A. S. Bondartsev & LE 3704 \\
\hline Leningrad Region & unidentified substrate & 19 VIII 1960 & M. A. Bondartseva & LE 3702 \\
\hline Leningrad Region & Betula pubescens & 20 VII 2014 & I. V. Zmitrovich & LE 287527 \\
\hline Leningrad Region & Populus tremula & 05 VIII 2001 & I. V. Zmitrovich & LE 212955 \\
\hline Leningrad Region & Betula sp. & 23 VI 1997 & O. V. Morozova & LE 215053 \\
\hline Leningrad Region & unidentified substrate & $07 \times 2007$ & N. V. Psurtseva & LE 265028 \\
\hline Leningrad Region & unidentified substrate & VIII 1918 & V. P. Savich & LE 3716 \\
\hline Mari El Republic & Betula sp. & 14 VI 1938 & B. P. Vasilkov & LE 3708 \\
\hline Mari El Republic & Populus sp. & 03 VII 1935 & B. P. Vasilkov & LE 3713 \\
\hline Moscow Region & Betula sp. & 19 VIII 1925 & L. A. Lebedeva & LE 3715 \\
\hline Moscow Region & unidentified substrate & 17 VI 2016 & O. V. Anisimova & LE 315401 \\
\hline Orel Region & Betula sp. & 06 VIII 1912 & A. S. Bondartsev & LE 3718 \\
\hline Pskov Region & unidentified substrate & 23 VII 2002 & O. V. Morozova & LE 217599 \\
\hline Saint Petersburg & unidentified substrate & 27 IX 1994 & O. V. Morozova & LE 227995 \\
\hline Stavropol Territory & unidentified substrate & 15 VIII 1925 & A. I. Lobik & LE 3711 \\
\hline Tver Region & unidentified substrate & VII 1924 & L. A. Lebedeva & LE 3712 \\
\hline Vologda Region & Betula sp. & 25 VIII 2002 & E. S. Popov & LE 246368 \\
\hline \multicolumn{5}{|c|}{ Urals } \\
\hline Perm Territory & Populus tremula & 15 VIII 1994 & L. G. Perevedentseva & PERM 118-3 \\
\hline \multicolumn{5}{|c|}{ Siberia } \\
\hline Irkutsk Region & Populus tremula & 15 VIII 1983 & A. E. Kovalenko & LE 18116 \\
\hline Irkutsk Region & Betula sp. & 20 VIII 1947 & B. P. Vasilkov & LE 3710 \\
\hline Irkutsk Region & Betula sp. & 26 VIII 1947 & B. P. Vasilkov & LE 3714 \\
\hline Irkutsk Region & Betula sp. & 27 VIII 1947 & B. P. Vasilkov & LE 3707 \\
\hline Krasnoyarsk Territory & Betula sp. & 11 IX 1965 & A. L. Yavorskiy & LE 3705 \\
\hline
\end{tabular}


piloso-squamulosus Lj. Vassilieva (current name is Lignomyces vetlinianus) (Bulakh, 2015).

\section{Conclusion}

The Panus represents rather well-delimited genus belonging to merulioid phylogenetic radiation, whose morphotype on essential features of its organization is trametoid, but superficial habitual features make it closer to the lentinoid one. One of its essential features is the abundance of fibrohyphae which forms a textura intricata, slowly growing basidiocarps and strictly lamellate hymenophore. Apparently, such an adaptive structure was generated under the influence of arid and warm climate conditions at the different regions of the planet, and only 2 species, Panus conchatus, and P. lecomtei, have been irradiated into temperate latitudes, including Russian territory. The substrate spectrum of these fungi is determined by their insensitivity to the substrate moistening and best ability to colonize

Table 2

Herbarium data on distribution of Panus lecomtei over Russian territory and its substrate preferences

\begin{tabular}{|c|c|c|c|c|}
\hline Region & Substrata & Date of collection & Collector & $\begin{array}{c}\text { Herbarium } \\
\text { numbers }\end{array}$ \\
\hline \multicolumn{5}{|c|}{ European part } \\
\hline Adygeya Republic & Fagus sylvatica & V 1910 & N. Shestunov & $\begin{array}{l}\text { LE 5815, LE } \\
5817, \text { LE } 5827\end{array}$ \\
\hline Adygeya Republic & Fagus sylvatica & 18 IX 2003 & N. V. Psurtseva & LE 241942 \\
\hline Kirov Region & unidentified substrate & 23 VII 1921 & M. K. Khokhryakov & LE 5799 \\
\hline Krasnodar Territory & unidentified substrate & 13 VIII 2003 & N. V. Psurtseva & LE 227998 \\
\hline Krasnodar Territory & unidentified substrate & 31 VII 1979 & A. E. Kovalenko & LE 5837 \\
\hline Krasnodar Territory & unidentified substrate & 17 VII 1976 & A. E. Kovalenko & LE 5829 \\
\hline Leningrad Region & Betula pubescens & 06 VII 1998 & I. V. Zmitrovich & LE 214737 \\
\hline Mari El Republic & unidentified substrate & 10 VI 1932 & B. P. Vasilkov & LE 5832 \\
\hline $\begin{array}{l}\text { North Ossetia-Alainia } \\
\text { Republic }\end{array}$ & Carpinus betulus & $15 \mathrm{~V} 1925$ & Z. Chernetskaya & LE 5813 \\
\hline Penza Region & Betula sp. & 27 VII 1921 & Shtukenberg & LE 5841 \\
\hline Ryazan Region & unidentified substrate & IX 1960 & G. K. Milberg & LE 5828 \\
\hline Stavropol Territory & unidentified substrate & 24 VIII 1915 & A. I. Lobik & LE 5836 \\
\hline Voronezh Region & unidentified substrate & 1946 & V. Ya. Chastukhin & LE 5833 \\
\hline \multicolumn{5}{|c|}{ Urals } \\
\hline Perm Territory & Betula pendula & 25 VIII 1980 & L. G. Perevedentseva & PERM 118-1 \\
\hline Perm Territory & Betula pendula & 30 VIII 1985 & L. G. Perevedentseva & PERM 118-2 \\
\hline Perm Territory & Betula pendula & 22 VIII 1999 & L. G. Perevedentseva & PERM 118-4 \\
\hline Perm Territory & Betula pendula & 04 VIII 2004 & L. G. Perevedentseva & PERM 118-5 \\
\hline \multicolumn{5}{|c|}{ Siberia } \\
\hline Altai Republic & Betula sp. & 17 VIII 2008 & N. V. Psurtseva & LE 254518 \\
\hline Altai Republic & Betula sp. & 18 VIII 2008 & N. V. Psurtseva & LE 254519 \\
\hline Altai Republic & Populus sp. & VIII 1937 & R. Singer & LE 5842 \\
\hline Chita Region & unidentified substrate & V 08.1910 & no data & LE 5812 \\
\hline Irkutsk Region & Betula sp. & 20 VIII 1921 & T. Smirnov & LE 5804 \\
\hline Irkutsk Region & Betula sp. & 04 IX 1947 & B. P. Vasilkov & LE 5805 \\
\hline Tumen Region & unidentified substrate & 20 VI 1914 & Varentsov & LE 5831 \\
\hline Yakutia Republic & Larix sp. & 10VIII1908 & N. A. Palchevskiy & LE 5844 \\
\hline \multicolumn{5}{|c|}{ Far East } \\
\hline Amur Region & Quercus sp. & 17VII1959 & B. A. Tomilin & LE 5791 \\
\hline Amur Region & unidentified substrate & 13VI1910 & M. Korotkiy & LE 3663 \\
\hline Primorye Region & unidentified substrate & 1913 & V. L. Komarov & LE 3664 \\
\hline Primorye Region & unidentified substrate & 29VI1913 & V. L. Komarov & LE 5840 \\
\hline Primorye Region & Betula dahurica & 19VII1934 & B. Kolesnikov & LE 5797 \\
\hline Primorye Region & Quercus sp. & 15 VII 1952 & E. V. Volkova & LE 5808 \\
\hline Sakhalin Region & Larix decidua & 1960 & B. P. Vasilkov & LE 5839 \\
\hline Sakhalin Region & Sorbus aucuparia & 29 VIII 1954 & M. G. Tarabaev & LE 5820 \\
\hline
\end{tabular}


hardwood, so the greatest number of their finds can be made on stumps and large remnants of standformers of corresponding forest areas. In Russia, a reliable association of Panus species to Betula spp. and Populus spp. was revealed. An ecotypic differentiation of the genus Panus is related to the quality of substrate colonized. The basidiocarps, growing over top cuts of the stumps, are characterized by strong central stipe (P. conchatus var. torulosus, $P$. lecomtei var. semirudis), whereas basidiocarps with sublateral attachment are common on fallen logs. Certain chromatic aberrations $(P$. conchatus var. inconstans) are associated with an insolation regime of the habitat. During last years, the Panus representatives have attracted an interest in biomedical research development. Their resource potential estimation should proceed from the fact that within Russian territory, such areas as Middle Belt of European Russia, North Caucasus, Altai and other re- gions of Southern Siberia are promising for replenishing the strains of P. conchatus and P. lecomtei.

\section{Acknowledgements}

The authors are very grateful to N. I. Kalinovskaya for kindly provided photos of Panus conchatus. The work by I. V. Zmitrovich, M. A. Bondartseva, and A. E. Kovalenko was carried out in canvas of the State Task of Komarov Botanical Institute of the Russian Academy of Sciences named as "Biodiversity and spatial structure of fungi and myxomycetes communities in natural and anthropogenic ecosystems" (AAAA-A18-118031290108-6). All experimental work has been fully implemented on the equipment of the Center for collective use of scientific equipment "Cellular and molecular technology of studying plants and fungi" at the Komarov Botanical Institute of the Russian Academy of Sciences (Saint Petersburg).

\section{REFERENCES / ЛИТЕРАTУPA}

Berkeley M. J., Curtis M. A. 1859. Centuries of North American fungi. Ann. Mag. Nat. Hist. 4: 284-296.

Bulakh E. M. 2015. Fungi of the forests of Far East of Russia. Dalnauka, Vladivostok, 404 pp. [In Russian]. (Б्yлах $\boldsymbol{E}$. M. Грибы лесов Дальнего Востока России. Владивосток: Дальнаука, 2015. 404 с.).

Bulliard P. 1787. Herbier de la France ou collection complete des plantes indigènes de ce royaume. Paris, 1-603 pp.

Corner E. J. H. 1981. The agaric genera Lentinus, Panus, and Pleurotus, with particular reference to Malasyan species. Beih. Nova Hedwigia 69: 1-169.

Courtecuisse R., Duhem B. 1994. Guide des champignons de France et d'Europe. Lausanne, 476 pp.

Drechsler-Santos E. R., Wartchow F., Coimbra V. R. M., Gibertoni D. B., Cavalcanti M. A. Q. 2012. Studies on lentinoid fungi from the semi-arid region of Brazil. J. Torrey Bot. Soc. 139, 4: 437-446. DOI: 10.3159/TORREYD-12-00019.1.

Erkel G., Anke T., Sterner O. 1996. Inhibition of NF-kappa B activation by panepoxydone. Biochem. Biophys. Res. Commun. 226, 1: 214-221. DOI: 10.1006/bbrc.1996.1335.

Fries E. 1821. Systema mycologicum, sistens fungorum ordines, genera et species, huc usque cognitas, quas ad normam methodi naturalis determinavit, disposuii atque descripsit. Vol. 1. Gryphiswald, 520 pp.

Fries E. 1825. Systema orbis vegetabilis. Pars I. Plantae homonemae. Typographia Academica, Lund, 374 pp.

Fries E. 1836-1838. Epicrisis Systematis Mycologici seu Synopsis Hymenomycetum. Typographia Academica, Uppsala, $610 \mathrm{pp}$.

Grand E. A. 2004. Systematics and species concepts in the genera Lentinus Fr. and Panus Fr., with emphasis on the Lentinus tigrinus, L. crinitus and Panus lecomtei complexes. Doctoral dissertation. Tennessee, $116 \mathrm{pp}$.

Greuter W., McNeill J., Barrie F. R., Burdet H.-M., Demoulin V., Nicolson D. H., Silva P. C., Skog J. E., Trejane P., Turland N. J., Hawksworth D. L. 2000. International Code of Botanical Nomenclature (St. Louis Code). Koeltz Scientific Books, Köningstein.

Hansen L., Knudsen H. 1992. Nordic macromycetes. Nordsvamp, Copenhagen, 474 pp.

Hibbett D. S., Murakami S., Tsuneda A. 1993. Sporocarp ontogeny in Panus (Agaricomycotina): evolution and classification. Am. J. Bot. 80, 11: 1336-1348.

Johnson J. E., Methven A. 1994. Panus conchatus: Cultural characters and mating data. Mycologia 86, 1: 146150.

Justo A., Miettinen O., Floudas D., Ortiz-Santana B., Sjökvist E., Linder D., Nakasone K., Niemelä T., Larsson K.-H., Ryvarden L., Hibbett D. L. 2017. A revised family-level classification of the Polyporales (Basidiomycota). Fungal Biol. 121, 9: 798-824. DOI: 10.1016/j.funbio.2017.05.010.

Knudsen H., Vesterholt J. 2008. Funga Nordica: agaricoid, boletoid and cyphelloid genera. Nordsvamp, Copenhagen, $970 \mathrm{pp}$. 
Ko K. S., Jung H. S. 1999. Molecular phylogeny of Trametes and related genera. Antonie Van Leeuwenhoek. 75 , 3: 191-199.

Larsson K.-H. 2007. Re-thinking the classification of corticioid fungi. Mycol. Res. 111: 1040-1063. DOI: 10.1016/j.mycres.2007.08.001.

Lee J. S., Lim Y. W. 2010. Cerrena aurantiopora sp. nov. (Polyporaceae) from Eastern Asia. Mycologia 102: 211-216. DOI: $10.3852 / 09-048$.

Malkovský K. M. 1932. Über die europäischen Arten der Gattung Panus. Ann. Mycol. 30, 1/2: 10-80.

Miettinen O., Larsson K.-H. 2011. Sidera, a new genus in Hymenochaetales with poroid and hydnoid species. Mycol. Progress 10, 2: 131-141. DOI: 10.1007/s11557-010-0682-5

Miller O. K. 1967. The role of light in the fruiting of Panus fragilis. Can. J. Bot. 45, 11: 1939-1943.

Panus conchatus (Bull.) Fr., 1838 in GBIF Secretariat. GBIF Backbone Taxonomy. Checklist Dataset, 2018. URL: https://www.gbif.org/species/search?q=Panus\%20conchatus on 2018-02-07.

Panus neostrigosus Drechsler-Santos et Wartchow, 2012 in GBIF Secretariat. GBIF Backbone Taxonomy. Checklist Dataset, 2018. URL: https://www.gbif.org/species/search?q=Panus\%20neostrigosus on 2018-02-07.

Pegler D. N. 1983. The genus Lentinus: a world monograph. Her Majesty's stationary office, Kew Bulletin additional series X. L. 281 pp.

Persoon C. H. 1800. Commentarius, Schaefferi fungorum Bavariae indigenorum icones pictas, differentiis specificis etc. illustrans. Erlangen, $130 \mathrm{pp}$.

Persoon C. H. 1801. Synopsis methodica fungorum. Gotting, 706 pp.

Petersen R. H., Psurtseva N. V., Zmitrovich I. V., Chachuła P., Arslanov S. N., Hughes K. W. 2015. Lignomyces, a new genus of pleurotoid Agaricomycetes. Mycologia 107, 3: 1045-1054. DOI: 10.3852/14-355.

Petre C. V., Tănase C. 2013. Culture characteristics of 20 lignicolous basidiomycetes species that synthesize volatile organic compounds. An. Stiin. Univ. Al. I. Cuza 59, 2: 37-51.

Phillips R. 1981. Mushrooms and other fungi of Great Britain and Europe. Pan Books, London, 319 pp.

Ryvarden L. 1991. Genera of polypores. Nomenclature and taxonomy. Synopsis Fung. 5: 1-363.

Shotwell J. B., Hu S., Medina E., Abe M., Cole R., Crews C. M., Wood J. L. 2000. Efficient stereoselective synthesis of isopanepoixdone and panepoxidone: a re-assignment of relative configuration. Tetrahedron Lett. 41: 9639-9643. DOI: 10.1002/chem.201103988.

Singer R. 1951. The Agaricales (Mushrooms) in modern taxonomy. Lilloa 22: 1-832.

Singer R. 1962. The Agaricales in modern taxonomy. 2nd ed. Weinheim, 915 pp.

Singer R. 1975. The Agaricales in modern taxonomy. 3rd ed. J. Cramer, Vaduz, 912 pp.

Singer R. 1986. The Agaricales in modern taxonomy. 4th ed. Koeltz Scientific Books, Koenigstein, 981 pp.

Spirin W. A. 2002. Aphyllophorales of the Nizhegorod Region: species composition and ecological features. Cand. biol. Dissertation. St. Petersburg, 242 pp. [In Russian]. (Спирин В. A. Афиллофоровые грибы Нижегородской области: видовой состав и особенности экологии. Дисс. ... канд биол. наук. СПб., 2002. 242 с.).

Thümen F. 1877. Beiträge zur Pilze-Flora Sibiriens. Byulleten Moskovskogo obshchestva ispytateley prirody 54: $128-152$.

Vargas-Isla R., Ishikawa N. K. 2008. Optimal conditions of in vitro mycelial growth of Lentinus strigosus, an edible mushroom isolated in the Brazilian Amazon. Mycoscience 49: 215. DOI: 10.1007/S10267-007-0404-2.

Zerova M. Ya. 1974. Atlas of fungi of Ukraine. Kiev, 251 pp. [In Ukrainian]. (Зерова М. Я. Атлас грибів України. Киев, 1974. 251 с.).

Zhang M., Wu F., Wei Z., Xiao Y., Gong $\boldsymbol{W}$. 2006. Characterization and decolorization ability of a laccase from Panus rudis. Enzyme and Microbia Technology 39, 1: 92-97. DOI: 10.1016/j.enzmictec.2005.09.012.

Zhou P., Fu Ch., Fu Sh., Zhan H. 2014. Purification and characterization of white laccase from the white-rot fungus Panus conchatus. BioRecources 9, 2: 1964-1976. DOI: 10.1016/0922-338X(95)98183-L.

Zmitrovich I. V.2015. Anti-cancer metabolites of Basidiomycota and their molecular targets. Vestnik Permskogo universiteta. Biologya 3: 264-286 [In Russian]. (Змитрович И. В. Метаболиты базидиальных грибов, эффективные в терапии рака и их молекулярные мишени: Обзор // Вестник Пермского университета. Биология, 2015. Вып. 3. С. 264-286).

Zmitrovich I. V., Bondartseva M. A., Psurtseva N. V., Wasser S. P. 2017. Typification and characterization of Trametes multicolor (Agaricomycetes), a perspective species of medicinal mushrooms. Int. J. Medicinal Mushrooms 19, 2: 137-144. DOI: 10.1615/IntJMedMushrooms.v19.i2.50.

Zmitrovich I. V., Bondartseva M. A., Vasilyev N. P. 2016. The Meruliaceae of Russia. I. Bjerkandera. Turczaninowia 19, 1: 5-18. DOI: 10.14258/turczaninowia.19.1.1.

Zmitrovich I. V., Kovalenko A. E. 2016. Lentinoid and polyporoid fungi, two generic conglomerates containing important medicinal mushrooms in molecular perspective. Int. J. Medicinal Mushrooms 18, 1: 23-38. DOI: 10.1615/ IntJMedMushrooms.v18.i1.40

Zmitrovich I. V., Malysheva V.F.2013. Towards a phylogeny of Trametes alliance (Basidiomycota, Polyporales). Mikologiya i fitopatologiya 47, 6: 358-380. 
Zmitrovich I. V., Malysheva $\boldsymbol{V}$.F., Malysheva E. F. 2009. The hyphal types of polyporoid and pleurotoid fungi: a terminology revision. Ukrainian botanical journal 66, 1: 71-87 [In Russian]. (Змитрович И. В., Малышева В. Ф., Малышева $\boldsymbol{E}$. Ф. Типы гиф полипороидных и плевротоидных грибов: терминологическая ревизия // Укр. бот. журнал, 2009. Т. 66, № 1. С. 71-87).

Zmitrovich I. V., Malysheva V. F., Malysheva E. F., Spirin V. A. 2004. Pleurotoid fungi of Leningrad Region (with notes on rare and interesting East-European taxa). VIZR, St. Petersburg, 124 pp. [In Russian]. (Змитрович И. В., Малышева В. Ф., Малышева Е. Ф., Спирин В. А. Плевротоидные грибы Ленинградской области (с заметками о редких и интересных восточноевропейских таксонах). СПб.: Изд-во ВИЗР, 2004. 124 с.). 